\title{
MOLECULAR CHARACTERIZATION OF THE PATHOGEN CAUSING GREY MOLD IN STRAWBERRY AND ITS MANAGEMENT
}

\author{
JAMEEL, S. ${ }^{1}-$ REHMAN, A. ${ }^{1 *}-$ RAJPUT, N. A. $^{1}-$ SADIA, B. ${ }^{2}$ \\ ${ }^{1}$ Department of Plant Pathology, University of Agriculture Faisalabad, Pakistan \\ ${ }^{2}$ Centre of Agriculture Biochemistry and Biotechnology, University of Agriculture Faisalabad, \\ Pakistan \\ *Corresponding author \\ e-mail:arb041@gmail.com
}

(Received $16^{\text {th }}$ Aug 2021; accepted $23^{\text {rd }}$ Nov 2021)

\begin{abstract}
Strawberry is an important fruit crop, it has been attacked by a number of pathogens. Grey mold for strawberry is commonly caused by Botrytis cinerea, which is an important fungal pathogen causing diseases in many crops. Strawberry samples affected by grey mold showing typical symptoms like browning of the fruit part, ripening berries and rotted fruit with grey mold growth were collected from different strawberry growing areas of Punjab and The National Agriculture Research Center (NARC). The associated pathogens were isolated, purified and their morphological features were observed. Pathogenicity test was conducted on fruits and were re-isolated from inoculated portions. The fungal DNA was isolated from diseased samples by using CTAB protocol. To identify the pathogens on the molecular basis PCR products were attained and amplified through universal primers. The sequence of associated pathogens were analyzed by constructing phylogenetic tree and the identified pathogens were organized into specific clades including other similar species. Different groups of fungicides, antagonistic microorganisms and plant extracts were also evaluated in-vitro against isolated fungal pathogens through poisoned food technique. Among fungicides, antagonists and plant extracts dicarboximide \& benzimidazole, Trichoderma spp., Allium sativum and Mentha spicata can showed promising results against mycelial growth of B. cinerea.
\end{abstract}

Keywords: Fragaria ananassa, Botrytis. cinerea, fungicides, antagonists, plant extract

\section{Introduction}

Strawberry (Fragaria ananassa Duchesne) is a cherished fruit product all over the world (Basu et al., 2014). Its yields are drastically reduced each year owing to the attack of a wide number of fungal, viral and bacterial pathogens (Giampieri et al., 2015). Fungal infections are most common and damaging especially the gray mold caused by Botrytis cinerea as they attack the plant and fruit in field, storage and during transportation, making it quite unlikable for producers, buyers and consumers equal (Hasan et al., 2019). The pathogen B. cinerea causes serious losses in more than 200 crop species worldwide. Under wet conditions without application of fungicides, it can cause massive production losses of up to $80 \%$ (Petrasch et al., 2019). Diseased samples of grey mold of strawberry showing typical symptoms like browning or blackening of the fruit part, light brown lesions usually develop on the stem grey, dusty looking fungal growth on ripening berries and rotted fruit with velvety grey mold growth (Bertetti et al., 2008). The classification of Botrytis genus is largely depended on cultural and morphological characteristics. Morphological characteristics are important to ascertain the biology of pathogens but variability in growth, spore size and shape and pathogenicity has been reported in genus Botrytis. The molecular investigations 
confirmed the traditional identification methods. Characteristics like colony color, texture, conidium size etc. are useful in describing some species (Staats et al., 2007). Along with the morphological characters, molecular characterization is also very important. Being an important pathogenic fungus, it is important to find out the genetic diversity of B. cinerea through latest molecular tools. Some gene specific primers are also available that had been used in B. cinerea identification at species level (Rigotti et al., 2002). Ribosomal internal transcribed spacer (ITS) region had been formerly used. With the ease of genome sequencing and use of other online software for genomic analyses, more information is available nowadays (Elad et al., 2009). Globally based on latest investigations, B. cinerea ranked second due to its economic and scientific importance. Among the list of top 10 fungal plant pathogens. Nowadays, the major way to manage grey mold rot caused by B. cinerea is the use of chemical fungicides, which may be about $8 \%$ of all the world fungicide market (Dean et al., 2012). In recent years, concerns about pesticide residues in food crops and fungicide-resistant pathogens have led to a demand for alternative methods to control plant pathogens such as B. cinerea (Fillinger and Elad, 2016). A lot of information about prevalence and incidence of the disease in different strawberry producing countries is available but in Pakistan very limited information is available. Therefore, this work is planned to find out the pathogens associated with grey mold of strawberry, their morphological and molecular identification and their management using different approaches. This study will provide basis for the development of integrated disease management strategies in future (Grover and Moore, 1962).

\section{Materials and methods}

The survey was conducted during December to March of 2018-2019 in strawberry fields which were on fruiting stage. Different strawberry growing areas of Punjab province Narowal, and NARC Pakistan were surveyed for the collection of typical grey mold diseased samples. From every field, different leaves, flowers and fruits samples were collected.

\section{Isolation, purification and morphological identification}

A total of 50 samples of rotted fruits were collected in the month of Dec-Mar, 20182019 from each of the field and assessed for presence of Botrytis cinerea fungi at the Plant Disease Diagnostic Laboratory, University of Agriculture, Faisalabad. Collected infected strawberry fruits were cut into small pieces $(1$ to $2 \mathrm{~cm})$ and plating on potato dextrose agar (PDA). The resulted fungal pathogens were then purified using the hyphal tips technique (Tuite, 1969) on the PDA medium followed by preparation of fungal slants on PDA medium for further future studies. The germinating spore and fruiting body of pathogen were examined and observed using microscope (Nikon AZ100), at 10, 40 and $100 \mathrm{X}$ magnification and images were captured by using a digital camera.

\section{Pathogenicity test}

Healthy fruits were disinfected by using $70 \%$ alcohol and washed with distilled water. The fruits were then flooded in $1 \%$ hypochlorite and again rinsed with distilled water. All fruits were pierced with a sterile needle and, then, scattered with the spore suspension. The interspersed fruits were kept in humid chambers at the room 
temperature, with observations taken every $24 \mathrm{~h}$. Symptoms of the inoculated strawberry fruits were observed on daily basis until development of typical grey mold appearance. Moreover, re-isolation was also done from the inoculated fruits to confirm the Koch's postulate (Park et al., 2008).

\section{Molecular identification of grey mold of strawberry}

\section{DNA extraction and gel electrophoresis examination}

The DNA of fungal pathogen was extracted by modified CTAB method (Möller et al., 1992). Extracted DNA samples of associated pathogen were examined by electrophoresis, $1.0 \%$ (weight/volume) agarose gels were added in (0.5X TBE buffer) along with $(100 \mu \mathrm{g} / \mathrm{ml})$ of ethidium bromide $(100 \mu \mathrm{g} / \mathrm{ml})$. The associated DNA samples of pathogen were examined by electrophoresis in $1.0 \%(\mathrm{w} / \mathrm{v})$ agarose gels $(0.5 \mathrm{X}$ TBE buffer) and DNA bands of associated pathogen were viewed on computerized Gel DocEZimager and pictured the image of DNA band (Shih et al., 2002).

\section{PCR amplification}

PCR Amplification is done through ITS. ITS regions of rDNA of associated pathogen will be amplify by using ITS1 (5'TCCGTAGGTGAACCTGCGG 3) and ITS4 (5' TCCTCCGCTTATTGATATGC 3) respectively. A total of 15 isolates were tested for this purpose. Optimum conditions for PCR amplification will maintain and final step of Polymerase Chain Reaction amplification were completed by Green master mix (2X Dream Taq Green PCR) at volume of $15 \mu \mathrm{l}$. (Green Master mix) is a composition of (4 mM MgCl2) and $0.4 \mathrm{mM}$ of dNTPs, (dATP, dCTP, dGTP and dTTP). Specific forward and reverse (ITS1 and ITS4) primers at volume (0.1-1.0 $\mu \mathrm{M})$ were used for amplification DNA templates and finally (1-10 $\mu$ l) of nuclease free water was added to complete the volume of PCR reaction.

\section{Sequencing and phylogenetic analysis}

The amplified PCR product were sequenced (Sanger et al., 1977) method and phylogenetic tree was constructed by using the MEGA 7.0 software (Kumar et al., 2016). Sequences were then submitted at NCBI database and were further analyze by BLAST analysis.

\section{Management of grey mold of strawberry}

\section{In-vitro evaluation of different groups of fungicides}

Fungicides Benzimidazole (1,3-benzodiazole), Dicarboximide (N-octylbicycloheptene), Anilide (Aniline), Triazole (Metconazole + Propiconazole) Anilinopyrimidine (Cyprodinil + Pyrimethanil) and Pyrazole (4-hydroxypyrazole) were tested in-vitro to evaluate suppression of mycelial growth of grey mold pathogen using the "poisoned food technique". 50, 100, 150, 200 and $250 \mu \mathrm{g} / \mathrm{mL}$ concentrations were made for each fungicide. Percent mycelial growth inhibition was calculated as given below:

$$
\text { Mycelial growth inhibition }=\frac{\mathrm{x}-\mathrm{Y}}{\mathrm{x}} \times 100
$$

where: $\mathrm{X}=$ radial growth of control plate; $\mathrm{Y}=$ radial growth of fungicide treated plate. 


\section{In-vitro management of grey mold through plant extracts}

Different plant extracts were evaluated in-vitro under different concentrations to determine the most efficient one. Table 1 showed the plant extracts that were used with their scientific and common names, families and plant parts that were used against grey mold of strawberry. Three concentrations were used with 7 treatments along with distilled water as negative control and 3 replications were done.

Table 1. List of different plant extracts used against grey mold of strawberry

\begin{tabular}{c|c|c|c|c}
\hline Sr. no & Scientific name & Common name & Family & Plant part used \\
\hline 1 & Allium sativum & Garlic & Amaryllidaceae & Pods \\
2 & Mentha spp. & Mint & Lamiaceae & Leaves \\
3 & Rosmarinu sofficinalis L. & Rosemary & Lamiaceae & Leaves \\
4 & Achillea millefolium & Yarrow & Asteraceae & Leaves \\
5 & Tagetes patula & Marygold & Asteraceae & Leaves \\
6 & Syzygium cumini & Jambolan & Myrtaceae & Leaves \\
\hline
\end{tabular}

\section{Preparation of plant extracts}

Plant parts after collections were surface sterilized and dried under shade conditions. After this, these samples were grind thoroughly using liquid nitrogen and extracted ( $48 \mathrm{~h}$ ) in a Soxhlet apparatus by using with absolute ethanol and methanol solvents. These solvents were removed separately using a rotary evaporator (Heidolph VV2000) under reduced pressure at $<50{ }^{\circ} \mathrm{C}$. Resulted crude extracts were kept at $20^{\circ} \mathrm{C}$ for storage until assayed. Stock solutions and serial dilutions of extracts were prepared in dimethyl sulphoxide (DMSO) (Fillinger and Elad, 2016). For control, DMSO was used.

Antifungal activity of selected medicinal plants Allium sativum, Mentha spp., Rosmarinus officinalis., Achillea millefolium, Tagetespatula and Syzygium cumini was evaluated against grey mold associated pathogen using an agar well diffusion method (Perez et al., 1990). PDA media was prepared for this purpose and petri plates were poured with $20 \mathrm{ml}$ media after sterilization in autoclave at $15 \mathrm{psi}$ and $121^{\circ} \mathrm{C}$. After solidification of media, four wells of $6 \mathrm{~mm}$ dia. were made in each petri plate with the help of sterilized cork borer. 5, 15, 25 and $50 \mu \mathrm{g} / \mathrm{mL}$ concentrations were prepared in DMSO and applied in each well using a micropipette. A purified colony of fungus $(5 \mathrm{~mm})$ was placed in the center of each petri plate and incubated at $25^{\circ} \mathrm{C}$. Three replications were used. Control treatment was performed by using DMSO with the same concentration used to test the extracts.

$$
\text { Diameter of inhibition zone }=\frac{\text { diameter of sample-diameter of control }}{\text { diameter of control }}
$$

\section{In-vitro management of grey mold through antagonistic microbes}

Following are the antagonistic microbes that were used. List of different antagonists are shown in Table 2.

Three concentrations were used with 7 treatments along with sterile water as negative control and 3 replications were performed for each treatment. All the in-vitro experiments were conducted using Poisoned Food Technique.100, 200 and $300 \mu \mathrm{g} / \mathrm{mL}$ 
concentrations were made for each antagonist. Percent mycelial growth inhibition was calculated as given below:

$$
\text { Mycelial growth inhibition }=\frac{\mathrm{X}-\mathrm{Y}}{\mathrm{x}} \times 100
$$

where: $\mathrm{X}=$ radial growth of control plate; $\mathrm{Y}=$ radial growth of antagonist treated plate.

Table 2. List of different antagonists used against grey mold of strawberry

\begin{tabular}{c|c|c}
\hline Sr. no & Antagonists & Organism type \\
\hline 1 & Colletotrichum gloeosporioides & Fungi \\
2 & Bacillus subtilis & Bacteria \\
3 & Burkholderia cepacian & Bacteria \\
4 & Aspergillus fumigatus & Fungi \\
5 & Trichoderma spp. & Fungi \\
6 & Penicillium spp. & Fungi \\
\hline
\end{tabular}

\section{Statistical analysis}

CRD was used for conducting all the experiments which were executed twice. There was no significant interaction between the two tests applied for any treatment used in experiments. After that, all the results were compiled for the final analysis from duplicate tests. Statistix ${ }^{\circledR} 8.1$ software was used for data analysis statistically. Overall significance of data was checked by ANOVA and differences among the treatment means were compared by using Tukey's test $(\mathrm{P} \leq 0.05)$ (Steel et al., 1997).

\section{Results}

\section{Isolation, purification and morphological identification of grey mold pathogen}

Isolation of fungal pathogens from district Narowal and NARC

Multiple samples of diseased plants (i.e., infected fruit parts) were collected from various strawberry fields, each of these samples were treated on following standard procedures and pure fungal mycelia were grown under optimum conditions, each of these fully grown cultures were compared with previously reported cultures, all purified cultures gave a typical greyish-brownish culture growth when compared after 6 and 10 days of culturing which was a positive response for grey mold pathogen (i.e., Botrytis cinerea). The maximum $(7.05 \%)$ fungi were collected from fruits followed by leaves $(2.56 \%)$ and flowers $(1.43 \%)$ from district Narowal (Table 3a). Whilst from NARC, the maximum (6.91\%) fungi were collected from fruits followed by leaves $(2.55 \%)$ and flowers $(1.76 \%)$ (Table $3 b)$. Data of the colonization of isolated fungal pathogens from rotted fruit revealed that almost all the field samples were colonized by three or more pathogens. From Kanjroor (Narowal) samples, the frequency of fungi with the highest incidence from district Narowal was Botrytis cinerea with the mean frequency of $(9.14 \%)$ followed by Alternaria alternate (5.79\%), Macrophomina (4.41\%), Rhizoctonia (3.56\%), Mucor (2.54\%), Curvularia (1.12\%), Rhizopus (1.70\%) and Aspergillus (0.75\%) (Table 3a). From NARC samples, the pathogen with the highest incidence from rotted fruits was Botrytis cinerea with the mean frequency 
of $(10.09 \%)$ followed by Alternaria alternate (6.07\%), Macrophomina (4.27\%), Rhizoctonia (3.49\%), Mucor (3.21\%), Rhizopus (1.05\%), Curvularia (0.79\%), and Aspergillus (0.91\%) (Table $3 b)$.

Table 3a. Frequency of fungi (per cent) isolated from different plant parts of strawberry collected from district Narowal

\begin{tabular}{c|c|c|c|c}
\hline \multirow{2}{*}{ Fungi } & \multicolumn{4}{|c}{ Plant parts } \\
\cline { 2 - 5 } & Leaves & Fruits & Flowers & Mean \\
\hline Botrytis cinerea (Nar) & 5.87 & 18.05 & 3.52 & 9.14 \\
Alternaria alternata & 4.26 & 11.03 & 2.09 & 5.79 \\
Aspergillus niger & 0.16 & 1.91 & 0.18 & 0.75 \\
Macrophomina spp. & 3.11 & 9.06 & 1.06 & 4.41 \\
Rhizoctonia spp. & 2.50 & 7.19 & 1.00 & 3.56 \\
Curvularia spp. & 1.11 & 2.12 & 0.14 & 1.12 \\
Mucor spp. & 1.21 & 5.16 & 1.26 & 2.54 \\
Rhizopus spp. & 1.03 & 1.91 & 2.17 & 1.70 \\
Means & 2.56 & 7.05 & 1.43 & \\
\hline
\end{tabular}

Table 3b. Frequency of fungi (per cent) isolated from different plant parts of strawberry collected from district NARC

\begin{tabular}{c|c|c|c|c}
\hline \multirow{2}{*}{ Fungi } & \multicolumn{4}{|c}{ Plant parts } \\
\cline { 2 - 5 } & Leaves & Fruits & Flowers & Mean \\
\hline Botrytis cinerea & 5.67 & 19.15 & 5.45 & 10.09 \\
Alternaria alternata & 4.62 & 12.01 & 1.60 & 6.07 \\
Aspergillus niger & 0.51 & 1.32 & 0.92 & 0.91 \\
Macrophomina spp. & 3.21 & 8.65 & 0.96 & 4.27 \\
Rhizoctonia spp. & 2.52 & 6.76 & 1.21 & 3.49 \\
Curvularia spp. & 1.25 & 0.82 & 0.31 & 0.79 \\
Mucor spp. & 1.42 & 5.56 & 2.66 & 3.21 \\
Rhizopus spp. & 1.21 & 0.95 & 1.01 & 1.05 \\
Means & 2.55 & 6.91 & 1.76 & \\
\hline
\end{tabular}

Data presented in Table $3 a$ and $b$ is presented as stacked bar chart in Figure 1. Incidence of fungal pathogens associated with strawberry plant from different sources of inoculum collected from different fields of NARC and district Narowal in Pakistan shows in Figure 1.

Followed by culture morphological identification, physical identification of growing conidiophores was carried out via a compound microscope. For the purpose lab microscope was utilized at all given magnification powers starting from the lowest up to maximum power of $100 \mathrm{X}$, under maximum magnification a conidiophore containing a tuft or cluster of egg-shaped, ellipsoidal conidia was easily observed confirming the presence of grey mold pathogen as shown in Figure 2.

\section{Pathogenicity test}

Followed by morphological identification a pathogenicity test was conducted in order to confirm the infection causing agent following the protocol given by Koch (Park 
et al., 2008). For the trial healthy plants were grown in green house followed by division of plan in to an experimental and a control group, where the experimental group was inoculated by purified pathogen suspension $(4 \times 106$ per $\mathrm{mL})$ and the control group was kept un-inoculated. Each of the group was grown under controlled optimal environment (i.e., temperature $21{ }^{\circ} \mathrm{C}$ and $\mathrm{RH}>90 \%$ ) for next 28 days, after seven days the experimental group plants began to show signs of infection with soft rot observed all over the plant body, after 10 days the collapse of functional parenchyma tissues was evident which indicated rapid increase in the rate of infection and was in line with the typical infectious pattern of B. cinerea, after 15 days fruit organs appeared shriveled and collapsed due to infection with evident growth of fungus observed on the surface of plant organs, after 21 days complete collapse of fruits was evident along with greyish fungal growth on the surface and pale yellow spots easily seen all over the adjacent leaves. In comparison to this the control group was completely protected from the infection with no appearance of any symptoms on them. Significant reduction in yield of the experimental (ranging around 24-25\%) was also observed in comparison to the control group. Comparison between pathogenicity of Narowal and NARC isolates are shown in Table 4. Pathogenicity test were perform only to see the presence and confirmation of pathogen but not for the yield reduction.

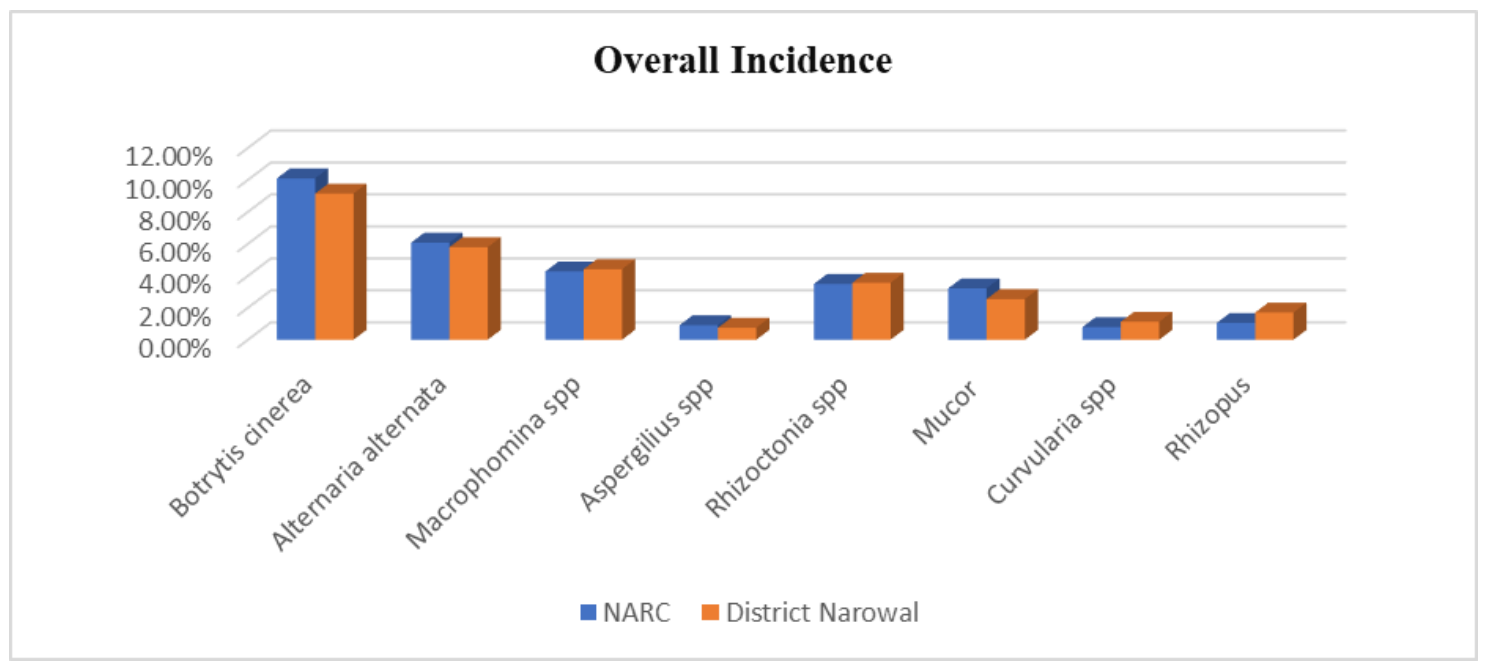

Figure 1. Overall incidence of colonization of fungal pathogens associated with strawberry plant from different sources of inoculum collected from different fields of NARC and district Narowal in Pakistan

Table 4. Comparison between pathogenicity of Narowal and NARC isolate

\begin{tabular}{c|c|c|c|c}
\hline \multirow{2}{*}{ Days } & \multirow{2}{*}{ Infection stage } & \multicolumn{2}{|c|}{ Experimental group } & \multirow{2}{*}{ Control group } \\
\cline { 3 - 4 } & & NARC isolate & Narowal isolate & \\
\hline 7 & Visible Soft rot & Yes & Yes & No \\
10 & Collapse of parenchyma cells & Yes & Yes & No \\
15 & Shriveled fruit & Yes & Yes & No \\
21 & Greyish fungal growth & Yes & Yes & No \\
\hline
\end{tabular}



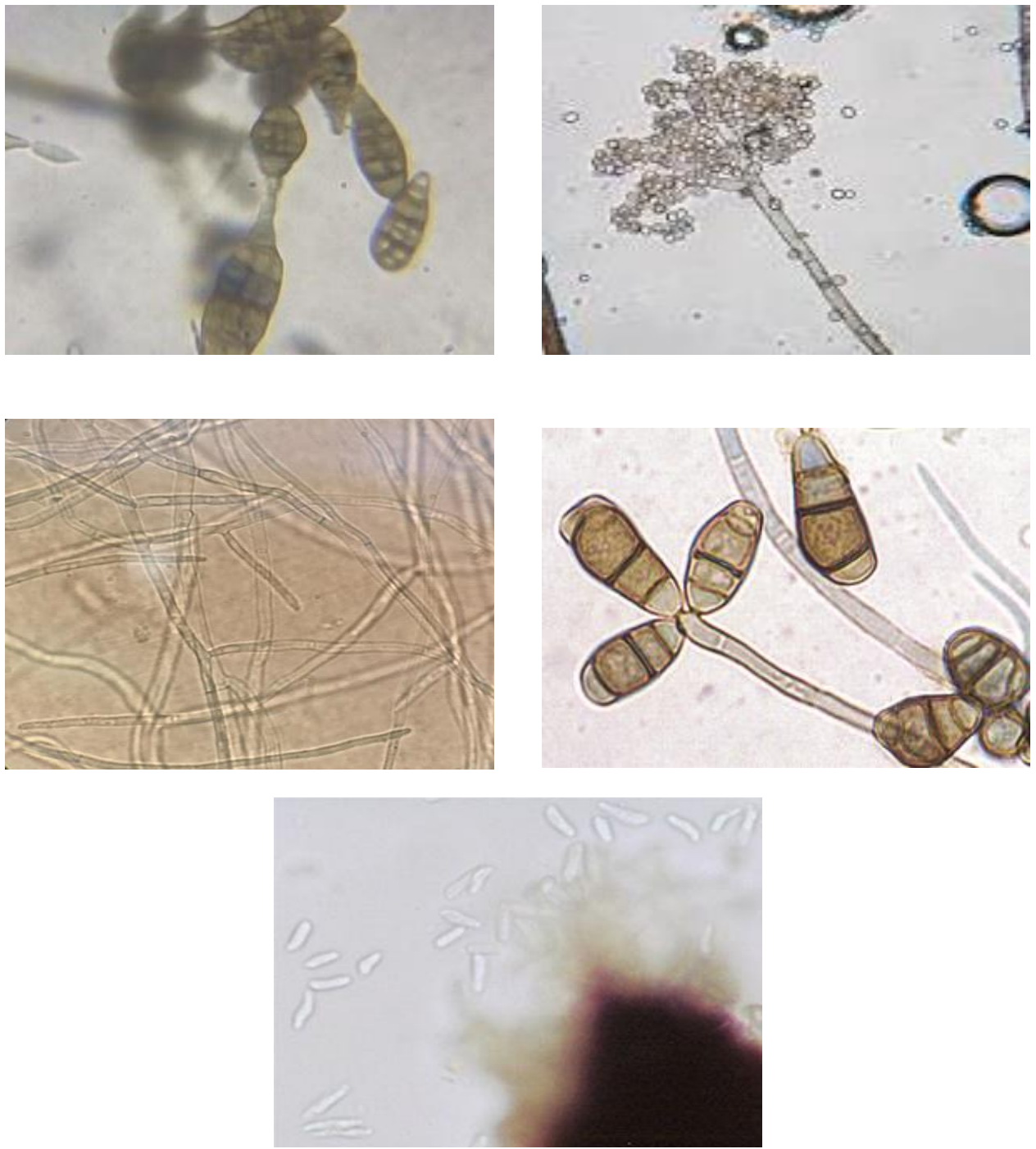

Figure 2. Microphotographs of isolates isolated from different disease samples infected (a) Alternaria, (b) Rhizopus spp, (c) Rhizoctonia spp), (d) Curbvularia spp, (e) Macrophomina spp

\section{Molecular identification and phylogenetic analysis: identification on the basis of gapA gene}

As illustrated from above experiments (the incidence of colonization of fugal pathogen) it is clarified that Botrytis cinerea were the only pathogen involved in the grey mold disease of strawberry, therefore we selected Botrytis cinerea for further studies. For genetic identification ITS region of $18 \mathrm{~S}$ rRNA gene was amplified for the 5 representative B. cineria isolates by using ITS 1 and ITS 4 primer (explained in materials and methods). The BLAST searches using NCBI (http://www.ncbi.nlm.nih.gov) and phylogenetic analyses using Maximum likelihood method (Mega7) revealed that the nucleotide sequences of all 5 isolates were identical to B. cinerea (WBD, 2018) Phylogenetic trees of all the strains are shown in Figure 3.

These five sequences were submitted to GenBank with the following accession numbers SUB8901212 Seq1 MW485211, SUB8901212 Seq2 MW485212, SUB8901212 Seq3 MW485213, SUB8901212 Seq4 MW485214, SUB8901212 Seq5 MW485215. 


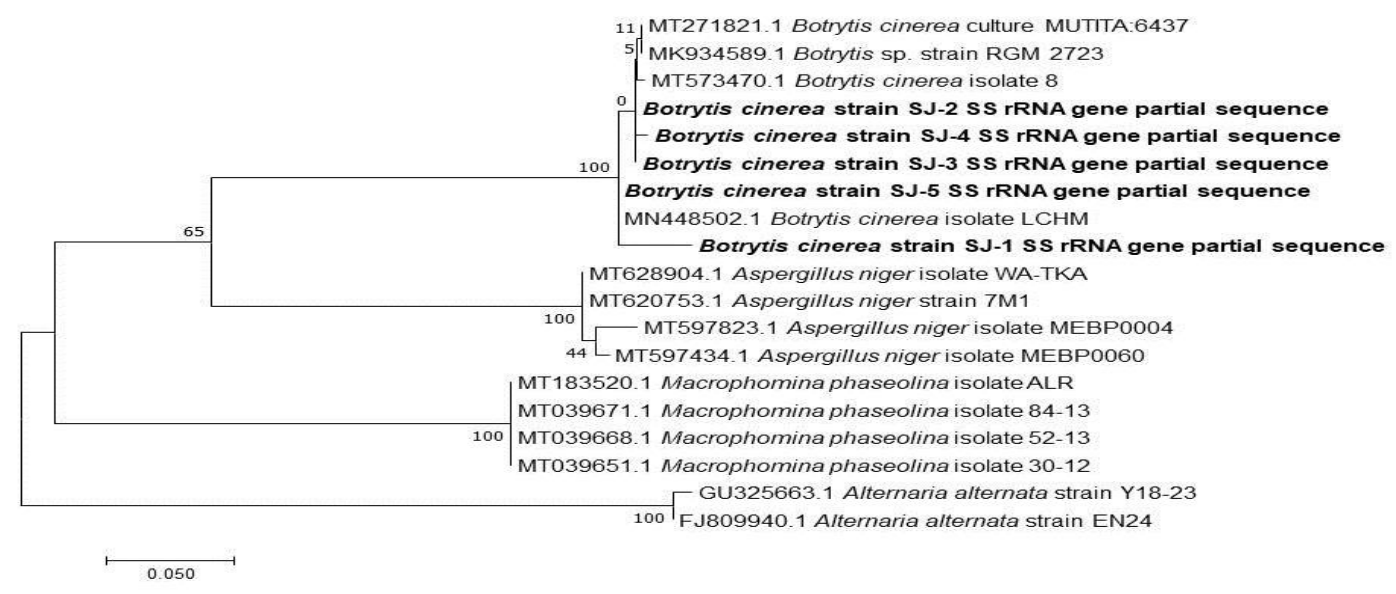

Figure 3. Molecular phylogenetic analysis by maximum likelihood method

The evolutionary history was inferred by using the Maximum Likelihood method based on the Tamura-Nei model. The analysis involved 19 nucleotide sequences. There were a total of 656 positions in the final dataset. Evolutionary analyses were conducted in MEGA7 (Kumar et al., 2016). Aspergillus niger, Macrophomina phaseolina and Alternaria alternate species were used as out-group species for rooting the tree.

\section{In-vitro evaluation of various fungicides, antagonists and plant extracts on the mycelial growth of Botrytis cinerea NARC and Narowal isolate}

The mean square values for various fungicides, antagonists and plant extracts showed significant effects on mycelia growth of Botrytis cinerea from samples collected from two different locations i.e., NARC and Narowal. In comparison to the control all fungicides treatments gave a significant response against the fungal growth with Dicarboximide giving best result followed by Benzimidazole, Anilinoptrimidine, Trizole, Pyrazole and anilide at both locations i.e., NARC and Narowal (Table 5). This massive difference of growth values between control and each of the treatments give a general view of the fact that each of these treatments has a significant inhibitory effect on the growth of pathogen. Certain of these chemicals gave slightly better results against Narowal isolates than the NARC isolates where as some showed a slight increase in the overall growth of the pathogen, this anomaly can be due to fungus natural ability to develop a certain degree of resistance against the chemicals. A trial was conducted with the technical evaluation of antagonist's inhibitory effect carried out against two isolates of strawberry grey mold to estimate the overall efficacy of antagonist agents, a total of seven treatments; with six antagonists and one control were applied on to the fungus under in-vitro conditions and the final results were evaluated. The application of antagonists against NARC and Narowal isolates showed that each of the antagonist treatments gave a significant response in reducing the growing ability of the pathogen in reference to the control, which shows ability to reduce pathogen infection in host plants. In case of NARC and Narowal isolates, among all antagonist treatments, Trichoderma spp. gave best results followed by Bacillus subtilis, Penicillium spp., Burkholderia spp., Aspergillus spp., and Colletotrichum spp. 
respectively Plant extracts is also considered to be one of the eco-friendly methods to inhibit the growth of certain pathogens. For the purpose of evaluating various extracts against Botrytis cinerea an experiment was carried out for estimating the effectiveness of plant extracts on growth reduction of two isolates. A total of six plant extracts and a control were evaluated against the pathogen. The application of different plant extracts against NARC and Narowal isolates revealed that Allium sativum was most effective followed by Mentha spicata, Tagetes patula, Syzygium cumini, Rosmarinus officinalis, and Achillea millefolium. This massive difference of growth values between control and each of the treatments give a general view of the fact that each of these treatments has a significant inhibitory effect on the growth of pathogen.

Table 5. Mean square values for In-vitro evaluation of various fungicide, antagonists and plant extracts on the mycelia growth of Botrytis cinerea

\begin{tabular}{c|c|c|c|c|c|c|c}
\hline Source & DF & $\begin{array}{c}\text { Fungicides } \\
\text { NARC }\end{array}$ & $\begin{array}{c}\text { Fungicides } \\
\text { Narowal }\end{array}$ & $\begin{array}{c}\text { Antagonists } \\
\text { NARC }\end{array}$ & $\begin{array}{c}\text { Antagonists } \\
\text { Narowal }\end{array}$ & $\begin{array}{c}\text { Plant extracts } \\
\text { NARC }\end{array}$ & $\begin{array}{c}\text { Plant extracts } \\
\text { Narowal }\end{array}$ \\
\hline Rep & 2 & 2.741 & 0.181 & 4.274 & 0.557 & 1.268 & 5.676 \\
Treatment & 6 & $860.471^{*}$ & $955.340^{*}$ & $507.759^{*}$ & $531.314^{*}$ & $396.912^{*}$ & $445.723^{*}$ \\
Error & 12 & 0.552 & 0.694 & 1.321 & 1.702 & 0.497 & 0.397 \\
Total & 20 & & & & & & \\
\hline
\end{tabular}

$\mathrm{CV}=4.37$

\section{Response of different groups of treatments on mycelial growth of Botrytis cinerea}

In order to estimate a group-based effectiveness of various chemicals being utilized for inhibiting the growth and infection of fungus we ultimately compared the values of growth under various treatments against the NARC and Narowal isolate. The overall comparison of different groups of treatments shows that each of the treatment type has particularly positive response in inhibiting the growth of fungus and thus preventing the infection. Among the treatments fungicidal treatments were most effective in reducing the infection followed by antagonists and plant extracts. Overall comparison of three groups of treatments over two-year time period is shown in Figure 4.

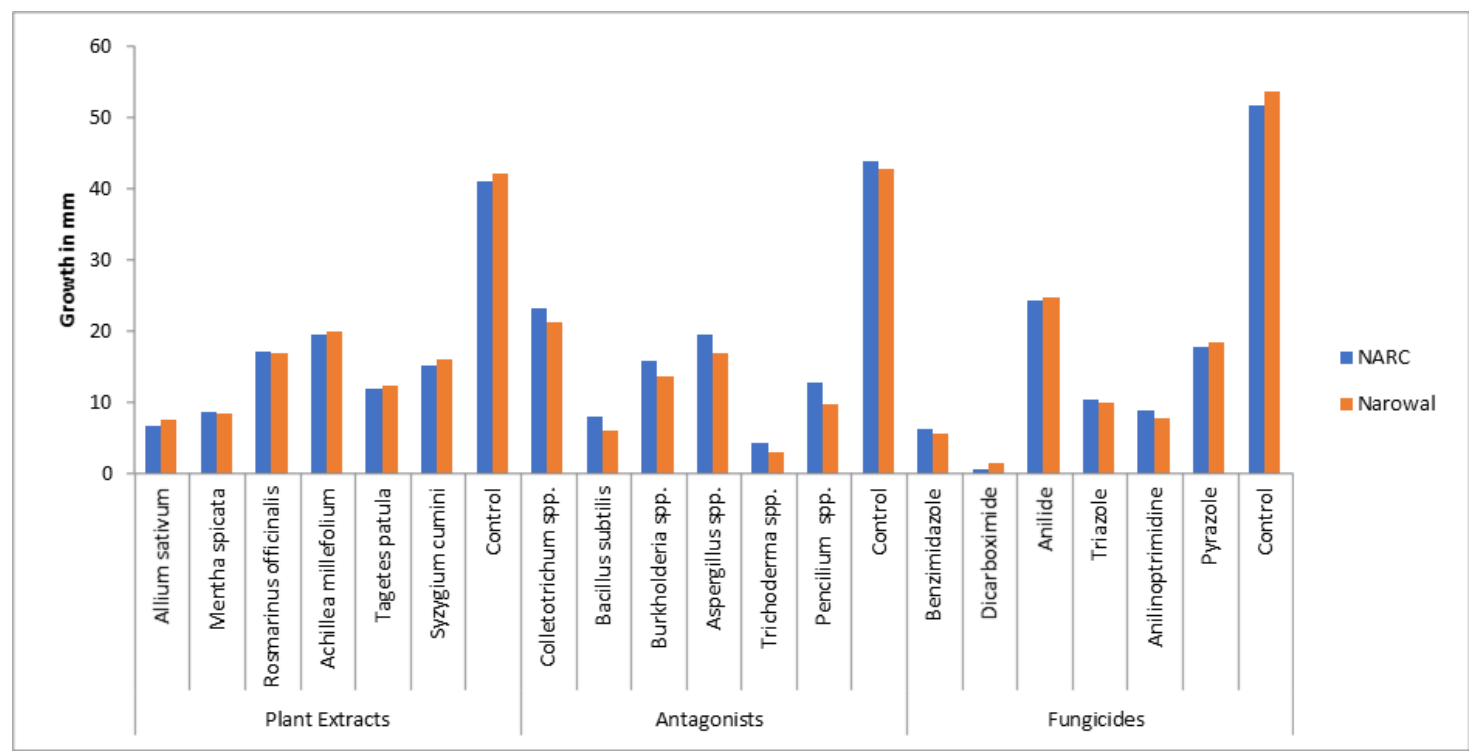

Figure 4. Response of different groups of treatments on mycelial growth of Botrytis cinerea 


\section{Response of individual treatments on Botrytis cinerea}

For estimating the individual treatment effectiveness response against the fungal pathogen all treatment data for inhibition of growth against the two isolates (i.e., NARC and Narowal isolate) was collected together and plotted on a graph (Fig. 5). The plotted data carefully shows level of effectiveness for each of the individual treatment in comparison to the control group, all of the treatments turn out to be effective having a significant reducing effect on pathogen indicating each of these can be made a part of well-designed broad range integrated management plan for combating the disease. Among the effective treatment the most effective of all is Dicarboximide which is a chemical based fungicidal treatment and remains the most effective over the entire experimental duration maintaining its efficacy. Second most effective treatment is the Trichoderma spp. based antagonists approach used for combating the disease by utilizing the competitive and counters active natural ability of the antagonists against the pathogen. Third best of all the treatments was the plant extract of Allium sativum, among all the treatments Anillide gave least effective result against both isolates but notably it was still far more effective in comparison to the control as it gave significantly lower growths of fungus in comparison to the control group.

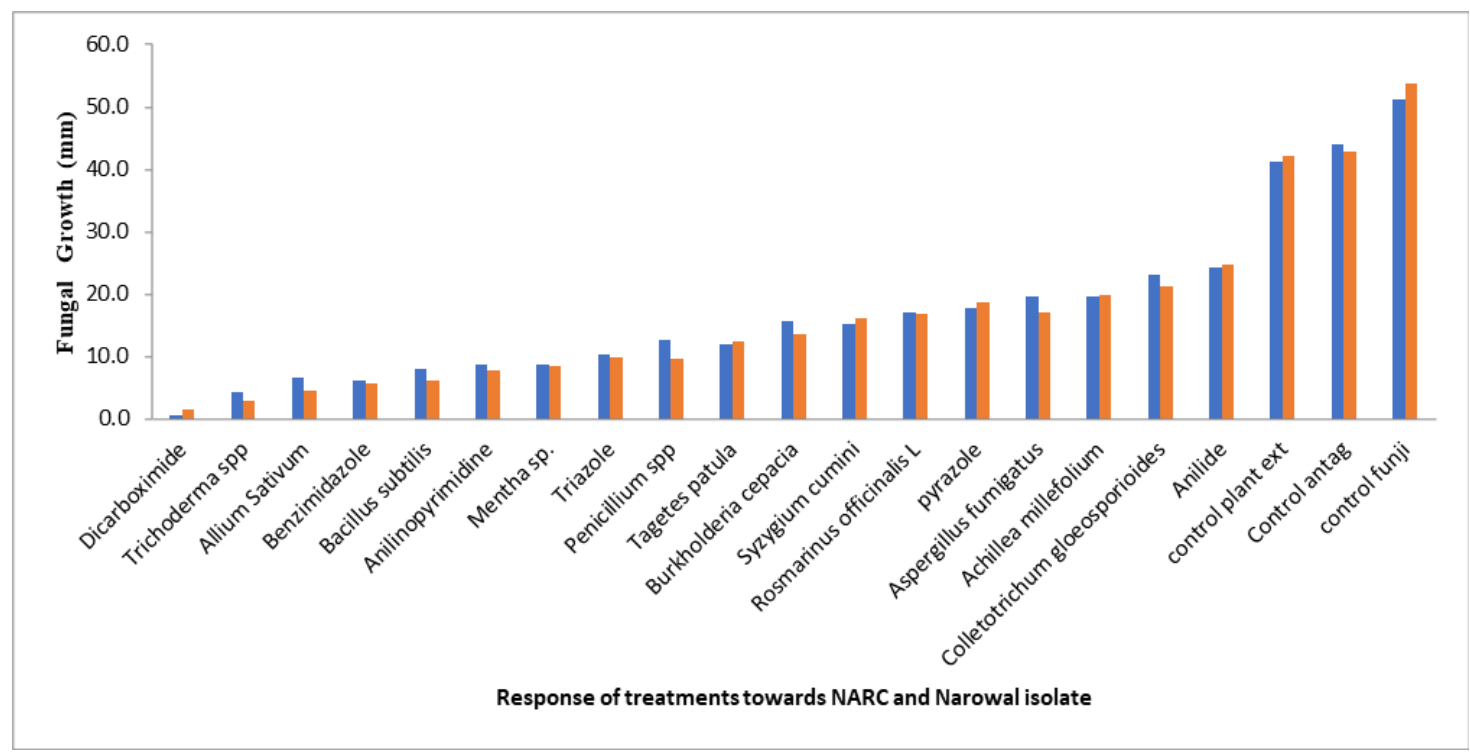

Figure 5. Response of individual treatments on Botrytis cinerea

\section{Discussion}

The fungal pathogen Botrytis cinerea causes grey mold, a commercially damaging disease of strawberry (Petrasch et al., 2019). During the first stage of the study, we carefully studied various symptoms of disease and conducted survey for visual analysis, we collected certain infected plant samples showing collapsed plant organs and parenchyma cells with watery soaked surfaces and greyish mold like appearances on collapsed fruit surfaces as all these symptoms matched with the one earlier explained by Barnes and Shaw The growing fungus from purified sample was carefully examined under microscope and results were in line. Initially different areas of Narowal and NARC were surveyed for the collection of typical grey mold diseased samples. The disease occurrence was more in NARC as compared to Narowal is attributed to high 
relative humidity during survey period (Hassan et al., 2019). The similar results were also reported by Card (2005). In this study, isolates of B. cinerea exhibited variation in cultural and morphological aspects. These differences were found to be due to geographical distribution of the studies isolates. Different studies also used cultural and morphological characters for tentative identification of B. cinerea (Fernández-Ortuño et al., 2012). Management of this disease to prevent yield losses is an extremely important process, for this purpose we carried out a series of trials under in-vitro conditions to estimate the effectiveness of wide range of fungicidal chemicals, antagonists and plant extracts for disease control. A total of six different fungicides were evaluated, each of them gave a significant response in counter acting the effect of fungus. Dicarboximide was the most effective fungicide followed by benzimidazole among all fungicides. Various studies reported that B. cinerea had developed resistance to dicarboximide, benzimidazole (Shao et al., 2021), Anilide (Stehmann and de Waard, 1996) Triazole (Stehmann and de Waard, 1996) and many other group of fungicide (Maia et al., 2021). Due to simultaneous resistance development against multiple fungicides and environmental concerns plant scientists are focusing on other integrative practices from last decades including biological and agricultural practice (Shao et al., 2021). Antagonistic microorganisms as a biological control agents have been suggested as a practicable approach to lessen the manifestation of various diseases on strawberries (Spadaro and Droby, 2016). In our study, invitro evaluation of six different antagonists were done to assess their efficacy against the pathogen. Each of them gave a significant response against the pathogen with the Trichoderma spp. giving best results of all followed by Bacillus subtilis, Pencillium spp., Burkholderia spp., and Colletotrichum spp. The results of our study are in line with the findings of Chen et al. (2019).

Under in-vitro conditions, six different extracts were prepared and evaluated, in general each of the extract gave a significant response against pathogens in comparison with the control group. The extract of Allium sativum revealed maximum inhibitory activities, followed by Mentha spicata, Tagetes patula, Syzygium cumini, Rosmarinus officinalis and Achillea millefolium respectively. The overall impact of Allium sativum extract on to the pathogen were promising and showed the potential of being used as an alternate to conventional chemicals, the results of our study are also supported by previous recorded results of Fufa and Kutawa. Both pre and postharvest practices and procedures are imperative in the ultimate control of fungal pathogens responsible for Grey mold disease. Based on our results, we recommend fungicides dicarboximide and benzimidazole showed promising results. Exploitable potential of extracts derived from Allium sativum and Mentha spicata can be used as an alternative to synthetic fungicides to control grey mold disease. Encouraging results were showed by Trichoderma spp. and Bacillus subtilis which is another biological control to avoid chemical possessions (Perez et al., 1990).

\section{Conclusions}

In conclusion, we showed the effectiveness of various group of fungicides, antagonists and plant extracts against mycelial growth of $B$. cinerea. Among fungicides, antagonists and plant extracts dicarboximide and benzimidazole, Trichoderma spp., Allium sativum and Mentha spicata can showed promising results against mycelial growth of $B$. cinerea. Our results provide basic information on the chemical and biological control of B. cinerea and are expected to contribute to future work. By using 
these management practices grey mold in strawberries could be controlled near future. These will also control post-harvest diseases in fruit crops.

\section{REFERENCES}

[1] Basu, A., Nguyen, A., Betts, N. M., Lyons, T. J. (2014): Strawberry as a functional food: an evidence-based review. - Critical Reviews in Food Science and Nutrition 54(6): 790806.

[2] Bertetti, D., Garibaldi, A., Gullino, M. (2008): Resistance of Botrytis cinerea to fungicides in Italian vineyards. - Communications in Agricultural and Applied Biological Sciences 73(2): 273-282.

[3] Card, S. D. (2005): Biological control of Botrytis cinerea in lettuce \& strawberry crops. A thesis submitted in partial fulfillment of the requirements for the Degree of Doctor of Philosophy at Lincoln University, Canterbury, New Zealand.

[4] Chen, X., Wang, Y., Gao, Y., Gao, T., Zhang, D. (2019): Inhibitory abilities of Bacillus isolates and their culture filtrates against the gray mold caused by Botrytis cinerea on postharvest fruit. - The Plant Pathology Journal 35(5): 425.

[5] Dean, R., Van Kan, J. A., Pretorius, Z. A., Hammond-Kosack, K. E., Di Pietro, A., Spanu, P. D., Rudd, J. J., Dickman, M., Kahmann, R., Ellis, J. (2012): The Top 10 fungal pathogens in molecular plant pathology. - Molecular Plant Pathology 13(4): 414-430.

[6] Fernández-Ortuño, D., Li, X., Wang, F., Schnabel, G. (2012): First report of gray mold of strawberry caused by Botrytis caroliniana in North Carolina. - Plant Disease 96(6): 914914.

[7] Giampieri, F., Forbes-Hernandez, T. Y., Gasparrini, M., Alvarez-Suarez, J. M., Afrin, S., Bompadre, S., Quiles, J. L., Mezzetti, B., Battino, M. (2015): Strawberry as a health promoter: an evidence based review. - Food \& Function 6(5): 1386-1398.

[8] Hassan, I., Mehmood, N., Riaz, A., Naz, F. (2019): Geographical distribution and morpho-molecular characterization of pre-harvest gray mold of strawberry in Punjab, Pakistan. - Mycopath 15(2).

[9] Kumar, S., Stecher, G., Tamura, K. (2016): MEGA7: molecular evolutionary genetics analysis version 7.0 for bigger datasets. - Molecular Biology and Evolution 33(7): 18701874.

[10] Maia, J. N., Beger, G., Pereira, W. V., De Mio, L. L. M., Duarte, H. d. S. S. (2021): Gray mold in strawberries in the Paraná state of Brazil is caused by Botrytis cinerea and its isolates exhibit multiple-fungicide resistance. - Crop Protection 140: 105415.

[11] Möller, E., Bahnweg, G., Sandermann, H., Geiger, H. (1992): A simple and efficient protocol for isolation of high molecular weight DNA from filamentous fungi, fruit bodies, and infected plant tissues. - Nucleic Acids Research 20(22): 6115.

[12] Park, D., Shafer, O. T., Shepherd, S. P., Suh, H., Trigg, J. S., Taghert, P. H. (2008): The Drosophila basic helix-loop-helix protein DIMMED directly activates PHM, a gene encoding a neuropeptide-amidating enzyme. - Molecular and Cellular Biology 28(1): 410-421.

[13] Petrasch, S., Knapp, S. J., Van Kan, J. A., Blanco-Ulate, B. (2019): Grey mould of strawberry, a devastating disease caused by the ubiquitous necrotrophic fungal pathogen Botrytis cinerea. - Molecular Plant Pathology 20(6): 877-892.

[14] Rigotti, S., Gindro, K., Richter, H., Viret, O. (2002): Characterization of molecular markers for specific and sensitive detection of Botrytis cinerea Pers.: Fr. in strawberry (Fragaria $\times$ ananassa Duch.) using PCR. - FEMS Microbiology Letters 209(2): 169-174.

[15] Sanger, F., Nicklen, S., Coulson, A. R. (1977): DNA sequencing with chain-terminating inhibitors. - Proceedings of the National Academy of Sciences 74(12): 5463-5467.

[16] Shao, W., Zhao, Y., Ma, Z. (2021): Advances in understanding fungicide resistance in Botrytis cinerea in China. - Phytopathology 111(3): 455-463. 
[17] Shih, M., Ambady, N., Richeson, J. A., Fujita, K., Gray, H. M. (2002): Stereotype performance boosts: the impact of self-relevance and the manner of stereotype activation. - Journal of Personality and Social Psychology 83(3): 638.

[18] Spadaro, D., Droby, S. (2016): Development of biocontrol products for postharvest diseases of fruit: the importance of elucidating the mechanisms of action of yeast antagonists. - Trends in Food Science \& Technology 47: 39-49.

[19] Staats, M., Van Baarlen, P., Schouten, A., Van Kan, J. A. (2007): Functional analysis of NLP genes from Botrytis elliptica. - Molecular Plant Pathology 8(2): 209-214.

[20] Stehmann, C., de Waard, M. A. (1996): Factors influencing activity of triazole fungicides towards Botrytis cinerea. - Crop Protection 15(1): 39-47.

[21] Tuite, J. (1969): Plant Pathological Methods. Fungi and Bacteria. - Burgess Publishing Company, Minneapolis, MN.

[22] Fufa, B. K. (2019): Anti-bacterial and anti-fungal properties of garlic extract (Allium sativum): a review. - Inter. J. Microbiol. Res. DOI: 10.9734/mrji/2019/v28i330133.

[23] Kutawa, A. B., Danladi, M. D., Haruna, A. (2018): Antifungal activity of garlic (Allium sativum) extract on some selected fungi. - J. Medi. Herbs Entho. Medi. DOI: https://doi.org/10.25081/jmhe.2018.v4.3383.

[24] Barnes, S., Shaw, M. (2003): Infection of commercial hybrid primula seed by Botrytis cinerea and latent disease spread through the plants. - Phyto. Pathol. 93: 573-578.

[25] Steel, R. G. D., Torrie, J. H., Deekey, D. A. (1997): Principles and Procedures of Statistics. A Biometrical Approach. 3rd Ed. - McGraw Hill Book Co. Inc, New York.

[26] Elad, Y., Williamson, B., Tudzynski, P., Delen, N. (2009): Botrytis spp. and diseases they cause in agricultural systems. An intro. - Botrytis. Bio. Pathol. Control. Springer, pp.1-8.

[27] Fillinger, S., Elad, Y. (2016): Botrytis: The Fungus, the Pathogen and Its Management in Agricultural Systems. - In: Elad, Y., Williamson, B., Tudzynski, P., Delen, N. (eds.) Botrytis: Biology, Pathology and Control. Springer, Dordrecht.

[28] Grover, R. K., Moore, J. D. (1962): Toximetric studies of fungicides against the brown rot organisms, Sclerotinia fructicola and S. laxa. - Phytopathology 52: 876-879.

[29] Perez, C., Paul, M., Bazerque, P. (1990): An antibiotic assay by agar well diffusion method. - Acta Biol. Med. Exp. 15: 113-115. 